EWA SOLARCZYK-AMBrOZIK

Uniwersytet im. Adama Mickiewicza

$w$ Poznaniu

\title{
DYNAMIKA ZMIAN W OBSZARZE PRACY A ROZWÓJ STUDIÓW KARIEROWYCH
}

\begin{abstract}
AвSTRACT. Solarczyk-Ambrozik Ewa, Dynamika zmian w obszarze pracy a rozwój studiów karierowych [Dynamic Changes in the Work Environment vs. the Development of Career Studies]. Studia Edukacyjne nr 47, 2018, Poznań 2018, pp. 49-68. Adam Mickiewicz University Press. ISSN 1233-6688. DOI: $10.14746 /$ se.2018.47.4
\end{abstract}

The widely accepted definition which relates a career to an individual's experience acquired during work, places it in the social space and in a specific time. The contextual and individual perspective provides an insight into the interrelationships between individual agency and the limiting or stimulating aspects of the social context. In career studies, it is emphasized that the concept of a career should be related to the category of work, because career is one of the key concepts used in Western societies of the twentieth century to describe the history of work understood as employment, despite the fact that new career theories go beyond this area of reference. The article discusses the development of career studies that reflect the transformation of the work environment. Attention is paid to the dynamic transformations in this environment are a background to changing career patterns and the relevant studies. The genealogical roots of contemporary career theories are shown, with special emphasis on their transdisciplinary nature. The article moreover focuses on problem areas inspired by the 1970s, which proved catalytic for modern career studies. The article concludes with reflections on the extent to which changes occurring in the area of work, and in particular experiencing discontinuities, pose a challenge to the fundamental principles and standards on which the theories, research and practices in the field of careers are based.

Key words: changes in work, career, changes in career patterns, career studies, transdisciplinarity, genealogical roots of career studies

Powszechnie akceptowana definicja kariery, rozumianej jako doświadczenia jednostki zdobywane $\mathrm{w}$ trakcie pracy, umiejscawia ją $\mathrm{w}$ przestrzeni społecznej i określonym czasie. Perspektywa kontekstualna i jednostkowa zapewnia spojrzenie na wzajemne powiązania jednostkowej sprawczości i ograniczające lub stymulujące aspekty społecznego kontekstu. W studiach 
karierowych podkreśla się, że koncepcja kariery powinna być powiązana z kategorią pracy, rozumianej jako zatrudnienie, choć w nowych teoriach karier wychodzi się poza ten obszar odniesień. Na przykład, M.B. Arthur i B.S. Lawrence podkreślają znaczenie wykonywanej pracy i czynności zawodowych dla określania tożsamości jednostki: „I am what I do” czy „My life is my work" ${ }^{1}$, podobnie w ujęciu J. Van Maanena praca stanowi punkt centralny, wokół którego jednostka organizuje swoje życie ${ }^{2}$. Znaczenie, jakie jednostki przypisują tak rozumianym karierom warunkowane jest również społecznie, odzwierciedlając społeczne, kulturowe i ekonomiczne wartości uznawane $\mathrm{w}$ danym społeczeństwie, czego przykładem jest $\mathrm{w}$ rynkowo zorientowanych społeczeństwach obok pracy sama wartość zatrudnienia, definiowanego jako zajmowanie wynagradzanego miejsca $\mathrm{w}$ formalnej strukturze organizacji, to jest hierarchii ról i kontroli. W takim ujęciu kariera traktowana jest jako „społecznie konstruowane środowisko jednostki, w którym jednostki i zbiorowości uczestniczą poprzez doświadczenie i proces nadawania znaczeń osadzonych w aktach społecznej komunikacji"3.

Jak wskazują R.A. Young i A. Collin, kariera była kluczowym pojęciem w zachodnich społeczeństwach XX wieku, używanym dla opisywania historii pracy oraz wzorów jej przeobrażeń, a także służyła innym społecznym celom. Przywiązanie jednostek poprzez karierę do rynków pracy w sposób dla nich personalnie znaczący, jak i będący równocześnie ważny dla społeczeństwa i organizacji, stanowi o tym, iż ma ona wkład w retorykę, która wpisuje się w różne ideologie społeczeństwa przyczyniając się do jego stabilności. Jak podkreślają cytowani autorzy, najogólniej kariera może odnosić się do przemieszczania się jednostki w czasie i przestrzeni społecznej, sekwencji wykonywanych zawodów i zajmowanych w trakcie życia zawodowego pozycji, może ogniskować się na styku indywidualnych biografii i społecznych struktur, może być używana jako określony konstrukt w akademickim i zawodowym dyskursie, czy też w organizacyjnej i społecznej retoryce. Czasami jednak jego retoryczne użycie może ukrywać swoje ideologiczne podstawy. Kariera może stanowić czynnik motywujący pracowników, czy też być źródłem perswazyjnego oddziaływania na nich ${ }^{4}$. W merytokratycznym i coraz bardziej zróżnicowanym społeczeństwie, w którym jednostkowy status osią-

\footnotetext{
${ }^{1}$ M.B. Arthur, B.S. Lawrence, Perspectives on environment and career. An introduction, Journal of Occupational Behaviour, 1984, 5, s. 1-2, za: D. Gowler, K. Legge, Rhetoric in bureaucratic careers: managing the meaning of management success, [w:] Handbook of Career Theory, red. M.B. Arthur, D.T. Hall, B.S. Lawrence, Cambridge 1996, s. 448.

2 J. Van Maanen, Organizational Careers: Some New Perspectives, New York 1977, za: D. Gowler, K. Legge, Rhetoric in bureaucratic careers, s. 4.

${ }^{3}$ D. Gowler, K. Legge, tamże, s. 449.

${ }^{4}$ R.A. Young, A. Collin, Introduction: framing the future of career, [w:] Future of Career, red. A. Collin, R.A. Young, Cambridge 2000, s. 3.
} 
gany jest poprzez edukację i w rezultacie społecznej mobilności, kariera stanowi znaczący symbol. Związany $\mathrm{z}$ etyką pracy termin wpisuje się $\mathrm{w}$ potencjał kontroli społecznej. Co jednak ważne, mając na uwadze przeobrażenia wzorów kariery, nie wszystkie jej formy są zakorzenione w organizacjach, niektóre, jak podkreślają A. Collin i R.A. Young, mogą nie być wcale związane z wykonywanym zawodem. Badacze ci stwierdzają, że kariera może obejmować dłuższą przestrzeń życia jednostki, niż przynależność jako pracownika do organizacji. Karierę utożsamiać można z tej perspektywy z historią życia jednostki opartą na pozycyjnych pasażach w jego biegu, nie tylko w czasie wykonywania pracy zawodowej.

Pomimo że historycznie rzecz ujmując, pojęcie kariery zrodziło się w zachodnim, indywidualistycznym, zindustrializowanym kontekście i na podstawie etyki promującej wolność wyboru, siły globalne przetransponowały je także w inne kulturowo i ekonomicznie lokacje ${ }^{6}$. Należy podkreślić przechodząc do dalszych analiz, że to właśnie dynamiczne zmiany w obrębie rynku pracy, zmiany jej charakteru, środowiska oraz ideologii pracy kształtowały $\mathrm{w}$ przestrzeni czasowej wzory przebiegu karier. Kamieniem milowym w procesie ewolucji pracy w społeczeństwach zachodnich była rewolucja przemysłowa, w której tradycyjna alokacja oparta na przesłankach klasowych straciła na znaczeniu. Praca stała się środkiem osobistego rozwoju i osiągania pozycji społecznej. W kontekście rewolucji przemysłowej i kultury reformacji zrodziło się pojęcie kariery zawodowej wyrastającej na jednostkowym zaangażowaniu w pracę, gromadzeniu doświadczenia, przygotowaniu i specjalizacji do całożyciowego jej rozwoju $\mathbf{u}^{7}$. Współcześnie podstawowy obszar przemian to zmiany w samej naturze pracy, ulegającej w coraz wyższym stopniu dematerializacji poprzez organizowanie jej coraz bardziej nie tylko wokół wytwarzania przedmiotów, ile wokół operowania abstraktami i ideami. Zjawisko to ma związek z przechodzeniem do gospodarki opartej na wiedzy ${ }^{8}$. Coraz częstsze operowanie $\mathrm{w}$ procesie pracy abstraktami i ideami powoduje przesunięcia w strukturze zatrudnienia, co oznacza liczbowe kurczenie się klasy robotniczej i wzrost liczebności zatrudnionych w sektorze usług. Ogólniejsze przemiany środowiska pracy rozmywają związek łączący ją ze strukturą zawodową jako ważnym czynnikiem umiejscowienia jednostki w sieci powiązań społecznych. Tracą na znaczeniu wyuczone kwalifikacje zawodowe, a praca zaczyna być organizowana wokół stale zmieniających się zadań, a nie

${ }^{5}$ Tamże, s. 4.

${ }^{6}$ S.A. Leung, The Big Five Career Theories [w:] International Handbook of Career Guidance, red. J.A. Athanasou, R. Van Esbroeck, Springer 2008, s. 115.

${ }^{7}$ G. Alurmani, Striking to Wright note: The cultural preparedness approach to developing resonant career guidance programme, International Journal for Education and Vocational Guidance 2011, 11.

8 M. Marody, Jednostka po nowoczesność. Perspektywa socjologiczna, Warszawa 2014, s. 130. 
pojedynczych czynności. Wzrost płynności zatrudnienia, indywidualne negocjowanie kontraktów na zmiennym rynku pracy i w konsekwencji bariery powstające dla organizowania się pracowników w korporacje zawodowe powodują to, że zawód traci na znaczeniu jako podstawowy składnik jednostkowej tożsamości ${ }^{9}$. Płynność zatrudnienia przekłada się na indywidualne strategie pracowników, co odzwierciedlają zmiany we wzorach przebiegu karier.

Z. Bauman mówiąc o zmiennej naturze pracy i strategii zarządzania podkreśla, że przez większą część ery nowoczesnej strategie zarządzania ogniskowały się na uczynieniu zachowań podwładnych maksymalnie zdeterminowanymi, co oznaczało przewidywalnymi. Jako filary instrumentalno-racjonalnego działania, stanowiącego podstawę realizacji celów, traktowano rutynę i ujednolicenie, pracownicy zaś uwolnieni byli od odpowiedzialności za rezultaty własnych działań. Wierzenia, przekonania, emocje, przyzwyczajenia pracowników lokowane były przez pracodawców po stronie „obciążeń"10. Idąc dalej tokiem wywodów Z. Baumana można stwierdzić, że wraz ze zmianami w organizacji pracy te same cechy pracowników, a szczególnie opór wobec uniformizacji, przenoszone są na stronę "zasobów”. Rezultaty pracy, jej efektywność zależą w coraz wyższym stopniu od kompetencji miękkich pracowników. Efektem takiej strategii jest przesunięcie odpowiedzialności za rezultaty pracy na pracowników, zaś odpowiedzialność menedżerów sprowadza się do właściwej ich selekcji. Jak zauważa cytowany autor, ta fundamentalna zmiana w praktyce zarządzania nie mogłaby dokonać się, gdyby nie deregulacja rynku pracy i warunków zatrudnienia oraz gdyby nie odwrót od praktyki zbiorowo negocjowanych warunków zatrudnienia, które zostały zastąpione indywidualizacją relacji między zatrudniającymi a zatrudnianymi ${ }^{11}$.

W pejzaż zmian w obszarze pracy wpisuje się również jej „nieciągłość”, co znajduje także swoje odzwierciedlenie we wzorach przebiegu karier. Pojęcie kariery traci swój tradycyjny sens. Nieczytelna, jak ujmują to M. Marody i L. Lewicki, struktura zawodów i rozmycie kryteriów awansu, dryfowanie od zatrudnienia do zatrudnienia, "horyzontalne ruchy” na ścieżce zawodowej powodują erozję dotychczasowego etosu pracy. Autorzy ci podkreślają, że na poziomie instytucjonalnym od pracownika oczekuje się cech instrumentalnych, co spowodowane jest tym, że zakres jego obowiązków nie zawsze jest sprecyzowany, a jakość pracy „rozpływa się” w zbiorowej odpowiedzialności za realizacje kolejnych projektów, co ma związek z korporacyjnymi ideolo-

\footnotetext{
9 Tamże, s. 135-136.

${ }^{10}$ Z. Bauman, Jak zmienia się natura pracy i działania w czasach bezkrólewia, „Krytyka Polityczna" z 28.01.2014, www:krytykapolityczna./pl/kraj/Bauman-jak-zmienia-się-natura-pracy-idzialania-w-czasach-bezkrólewia

11 Tamże.
} 
giami pracy zmierzającymi do „uczynienia z pracy centrum jednostkowego życia"12. Zanika standardowy model zatrudnienia na rzecz pracy elastycznej. M. Castells pisze, że „tradycyjna forma pracy, oparta na pełnoetatowym zatrudnieniu, ściśle określonych zadaniach i wzorcu kariery zawodowej na cale życie, ulega powolnej, lecz nieuchronnej erozji"13. Zmiany w obszarze pracy opisują także takie kategorie, jak elastyczność i mobilność. Na przykład, R. Sennett podkreśla znaczenie elastyczności jako podstawowej cechy neoliberalnego kapitalizmu nie tylko w obszarze pracy ${ }^{14}$. Nie dla wszystkich jednak zmienność i transgresja stanowią codzienne doświadczenie - mobilność jest również systemem hierarchicznym, charakteryzującym się specyficznymi strukturami hegemonicznymi, opartymi na wykluczeniu ${ }^{15}$, a prawo do mobilności można traktować jako przywilej regulowany przez zasady rządzące wolnym rynkiem, co również przejawia się w sferze pracy i organizacji. M. Castells zwraca uwagę, że sieciowa organizacja umożliwia zlecanie usług na zewnątrz i podwykonawstwo jako formy eksternalizacji pracy w elastycznej adaptacji do warunków rynku, podkreśla, że badacze trafnie rozróżniają formy elastyczności w płacach, mobilności geograficznej, statusie zawodowym, wykonywaniu zadań ${ }^{16}$. Wszystkie procesy gospodarcze i społeczne podlegają strukturalnie dominującej logice gospodarki informacyjnej, w efekcie czego kształtuje się społeczeństwo sieci, co ma istotny wpływ na przebieg karier zawodowych. Dla opisu transformacji pracy jako płaszczyzny transformacji wzorów karier oczywiste jest odniesienie się do zjawiska globalizacji. Globalna gospodarka, która rozprzestrzeniła się dzięki wykorzystaniu nowych technologii informacyjnych i komunikacyjnych, powoduje zjawisko, jakim jest globalne zatrudnienie $\mathrm{w}$ wielonarodowych korporacjach i ich ponadgranicznych sieciach oraz ze względu na wpływ globalnej konkurencji i nowego sposobu zarządzania siłą roboczą jej współzależność w skali globalnej ${ }^{17}$.

Zmiany zachodzące $w$ obszarze pracy oddziałują na przeobrażenia wzorów przebiegu karier, co ma także swoje odzwierciedlenie $\mathrm{w}$ dynamice studiów karierowych. Rewizjonistyczne podejścia do dominujących teorii karier sugerują położenie większego akcentu na zróżnicowane uwarunkowania rozwoju karier, czy też formułowanie nowych, mających miejsce w związku

${ }^{12}$ M. Marody, L. Lewicki, Przemiany ideologii pracy, [w:] Kultura i gospodarka, red. J. Kochanowicz, M. Marody, Warszawa 2010, s.125

${ }_{13}$ M. Castells, Społeczeństwo sieci, Warszawa 2013, s. 291.

${ }^{14}$ R. Sennett, Korozja charakteru. Osobiste konsekwencje pracy w nowym kapitalizmie, Warszawa 2006.

${ }^{15} \mathrm{~J}$. Burszta, Ruchome wyobraźnie. Reżim mobilności w neoliberalnym świecie, [w:] Zwodnicze imaginarium. Antropologia neoliberalizmu, red. W.J. Burszta, P. Jezierski, M. Rauszer, Gdańsk 2016, s. 305 .

${ }^{16}$ M. Castells, Społeczeństwo sieci, s. 295.

17 Tamże, s. 257. 
ze zmianami społeczno-środowiskowymi, lokalnymi, globalnymi, bądź też kulturowymi zmianami faz kariery lub cyklów uczenia się i ich inkorporacji do teorii rozwojowych ${ }^{18}$, co pozwoli opisywać i wyjaśniać ten złożony fenomen z uwzględnieniem zróżnicowania siły roboczej, zróżnicowania warunków organizacyjnych pracy i dynamicznie zmieniającego się zróżnicowania zawodowego.

Współczesne teorie karier, jak podkreślają badacze podejmujący problem ich rozwoju, mają swoje korzenie genealogiczne w studiach $\mathrm{z}$ dziedziny organizacji i zarządzania ${ }^{19}$. Na podkreślenie zasługuje jednak ich interdyscyplinarny charakter. Mając na uwadze dziedzictwo wcześniejszych teorii karier, wskazuje się na potrzebę wielodyscyplinarnego podejścia, lepiej służącego zarówno teorii karier, jak i wyrosłej na nich praktyce. Teorie karier budują forum dyskusyjne pozwalające badaczom przekroczyć granice własnych dyscyplin. Podstawową cechą opisu teorii karier, jak już zostało powiedziane, jest ich interdyscyplinarność i właśnie ta interdyscyplinarność problematyki karier jako pola badawczego powoduje trudności co do wyraźnego określenia intelektualnych jego korzeni.

C. Moore, H. Gunz i D.T. Hall wyróżniają dwa główne trendy wpływów na teorie karier. Pierwszy stanowi podkreślenie znaczenia dyscyplin bezpośrednio oddziałujących na ten obszar, jakimi są socjologia i psychologia. Mówiąc o znaczeniu socjologii i psychologii dla rozwoju studiów karierowych odwołują się do ustaleń J.A. Sonnenfelda i J.P. Kottera, którzy zidentyfikowali cztery dominujące obszary analiz dotyczące karier w tym zakresie literaturowym, jakie tworzą perspektywy:

1) socjologiczna, zogniskowana na społecznych i klasowych determinantach karier;

2) różnic indywidualnych, zogniskowana z kolei na predykcji tego, w jaki sposób te statyczne, dyspozycyjne różnice oddziałują na wybory karierowe i sukces w karierze;

3) rozwojowa, zorientowana na rozumienie dynamiki etapów kariery.

4) cyklów życia ${ }^{20}$.

Z kolei M.B. Arthur, D.T. Hall i B.S. Lawrence dokonując odwołań do literatury obszarowej opartej na psychologii i socjologii, wskazują na cztery typy teorii karier:

1) socjologiczne, koncentrujące się na klasowych determinantach karier;

18 D.T. Hall, P.H. Mirvis, The new protean career. Psychological success and the path with a heart, [w:] The career is dead - long live the career, red. D.T. Hall, San Francisco 1996.

19 C. Moore, H. Gunz, D.T. Hall, Tracing the Historical Roots of Career Theory in Management and Organizational Studies, [w:] Handbook of Career Studies, red. H. Gunz, M. Peiperl, Los Angeles 2007.

20 J.A. Sonnenfeld, J.P. Kotter, The maturation of career theory, Humans Relations, 1982, 35 , s. 19-46, za: C. Moore, H. Gunz, D.T. Hall, Tracing the Historical Roots, s. 14. 
2) psychologiczne, dotyczące statycznych różnic dyspozycyjnych i ich implikacji dla kształtu i przebiegu karier;

3) socjologiczno-psychologiczne, ogniskujące się na cyklach kariery i w związku z nimi na wyborach oraz rozwoju zawodowym;

4) najnowsze, w ujęciu tych autorów, ogniskujące się na szerszym pojęciu, jakim jest przebieg życia $\mathrm{w}$ dorosłości oraz dotyczące relacji karier $\mathrm{z}$ innymi obszarami aktywności człowieka dorosłego ${ }^{21}$.

W odniesieniu do psychologii karier, M. Savickas stwierdza, że dyscyplina powstała we wczesnych latach $X X$ wieku odpowiada na przemiany w obszarze pracy i społecznej organizacji. Punktem wyjściowym analiz jest założenie o wpływie zmian w obszarze warunków społecznych na zmiany organizacji pracy. Aktualne zmiany kontekstu kulturowego mogą wpływać zarówno na samo rozumienie pojęcia, jak i na doświadczenie kariery. M. Savickas zwraca uwagę, w kontekście historii Stanów Zjednoczonych, na różnicujący wpływ przemian ekonomicznych, analizując te wpływy w społeczeństwie rolniczym, przemysłowym i w społeczeństwie globalnej ekonomii, co owocowało zmianami i doświadczeniem karier. Współcześnie, jak podkreśla ten autor, podstawowe konstrukty wpisane w założenia modernistycznej psychologii ulegają rekonceptualizacji. M. Savickas stwierdza separację badaczy na dwa podstawowe obozy - psychologów broniących podejścia obiektywistycznego, przejawiającego się w modelu cechy i czynnika, i opartych na nim metod w doradztwie karier oraz psychologów rozwijających konstruktywistyczne metody będące wrażliwe na klientów stanowiących margines zainteresowań i działań obiektywistycznych praktyk. Warto jednak zwrócić uwagę, że taka dychotomia jest wyraźnym uproszczeniem. Jak podkreśla bowiem M. Savickas, nie obserwuje się współcześnie ataku na podejście cechy i czynnika, wręcz przeciwnie - niektórzy badacze budują na osiągnięciach tego podejścia tworząc suplementarne modele i materiały. Jednak postrzeganie kariery w zmiennym kontekście współczesnego świata oparte jest na nowych koncepcjach karier, postrzeganych bardziej personalnie oraz na ujmowaniu jednostki w studiach karierowych jako agenta zmian w przebiegu życia i wyrasta $\mathrm{z}$ inspiracji oraz wsparcia konstruktywistycznej metateorii ${ }^{22}$. Oparte na tym podejściu rozumienie kariery eksponuje aktywność jednostki w nadawaniu znaczeń i samozarządzaniu ścieżką rozwoju zawodowego. Warto dodać mając na uwadze praktyczne odniesienia studiów karierowych, w przypadku dokonania psychologii karier, że biograficzno-hermeneutyczne podejścia i narracyjne modele pozwalają na wyjście naprzeciw potrzebom

${ }^{21}$ M.B. Arthur, D.T. Hall, B.S. Lawrence, Generating new directions in career theory: the case for a transdisciplinary approach, [w:] Handbook of Career Theory, s. 9.

${ }^{22}$ M.L. Savickas, Renovating the psychology of career for the twenty - first century, [w:] The Future of Career, s. 50. 
klienta, który musi podejmować decyzje karierowe i planować życie w świecie dynamicznych zmian, pozwalają na wzmacnianie samorefleksji klienta i eksploracji różnych dróg aktywności, a także zachowań zawodowych ${ }^{23}$.

Drugi trend wpływu dyscyplin społecznych na teorie karier, wyróżnionych przez C. Moore, H. Gunz i D.T. Halla, stanowi szersze spojrzenie na historyczne podstawy tych teorii, uwzględniające obok wpływów socjologii i psychologii także wpływ filozofii, antropologii, ekonomii, czy nauk politycznych na rozwój analizowanych studiów. W próbie syntezy historycznych podstaw studiów karierowych cytowani autorzy zidentyfikowali pięć metatematów, które przekraczają interdyscyplinarne granice, jakimi są: 1) indywidualna sprawczość a społeczny determinizm w kształtowaniu karier; 2) kariera jako proces a kariera jako osiągnięcie dopasowania; 3) dopasowanie dla celów jednostkowych; 4) kariera jako zjawisko społeczne a kariera jako indywidualna historia życia; 5) teoria versus praktyka ${ }^{24}$.

Na problem interdyscyplinarności studiów karierowych zwracają też uwagę M.B. Arthur, D.T. Hall, B.S. Lawrence wskazując, iż koncepcja kariery nie należy wyłącznie do jakiegoś teoretycznego, czy dyscyplinarnego ujęcia, ujmowana jest bowiem w różnej perspektywie. Wyrażają przekonanie, że eksploracja tej różnorodności pozwala stawiać nowe pytania i poszukiwać nowych odpowiedzi, analizują tym samym teorie karier w powiązaniu $\mathrm{z}$ badaniami wielodyscyplinarnymi ${ }^{25}$. Wyraźnie artykułowana jest potrzeba wyjścia poza fragmentaryzację i konieczność budowy interdyscyplinarnych teorii o dużym zasięgu, potrzeba spojrzenia na ten sam problem z perspektywy różnych dyscyplin naukowych, z perspektywy różnych założeń leżących u podstaw tego samego problemu, czego przykładem może być połączenie psychologicznie ugruntowanych idei na temat rozwoju karier jednostkowych z perspektywą korporacyjnych strategii. Można by powiedzieć, że przyszłość studiów karierowych to interdyscyplinarność. Warunkiem tego jest silne zakorzenienie nowych teorii $\mathrm{w}$ dotychczasowym dorobku nauk społecznych stanowiących "korzenie drzewa genealogicznego" teorii karier. Jak podkreślają M.B. Arthur, D.T. Hall i B.S. Lawrence, u podstaw nowych koncepcji i dalszego rozwoju badań w dziedzinie kariery leżą dokonania psychologii pracy w zakresie relacji pomiędzy osobowością a zawodem, szczególnie odzwierciedlone w teoriach cechy i czynnika, osiągnięcia psychologii rozwoju człowieka dorosłego oraz osiągnięcia socjologii. Sięgając do podstaw teorii karier, cytowani badacze odwołują się do dorobku Socjologicznej Szkoły Chicagowskiej, a szczególnie do osiągnięć w zakresie struktur społecznych, własności wspólnej i zmian statusu, umożliwiających rozumienie tego, jak jed-

\footnotetext{
${ }^{23}$ Tamże.

${ }^{24}$ C. Moore, H. Gunz, D.T. Hall, Tracing the Historical Roots.

${ }^{25}$ M.B. Arthur, D.T. Hall, B.S. Lawrence (red.), Handbook of Career Theory.
} 
nostki podlegają procesom socjalizacji i jak same konstruują społeczne światy. Jako istotne dla rozumienia fenomenu kariery podkreślają także osiągnięcia socjologii w zakresie doświadczeń funkcjonowania jednostek w strukturach organizacyjnych, przy założeniu, że studia karierowe są także studiami nad zmianami organizacyjnymi ${ }^{26}$.

Warto za M.B. Arthurem, D.T. Hallem i B.S. Lawrence przytoczyć wybrane przykłady definicji karier w ujęciu dyscyplin społecznych, które ukazują, jak pojęcie kariery zapewnia podstawy dla przekraczania dyscyplinarnych granic.

Psychologia. Kariera jako zawód: podejście akceptujące tradycyjny w psychologii pogląd, iż osobowość osób dorosłych cechuje się stabilnością; teoria leżąca u podstaw tego podejścia ma pokierować jednostki i organizacje w kierunku obsadzania miejsc pracy w sposób zadowalający dla obu stron (np. Holland, 1985).

Kariera jako sposób na samorealizację: podejście humanistyczne skupiające się na wynikających z kariery możliwościach rozwoju osobistego oraz korzyściach wynikających z tego rozwoju dla organizacji i społeczeństwa (np. Shepard, 1984).

Kariera jako składowa struktury życia jednostki: w tym podejściu etapy kariery i okresy przejściowe między nimi da się przewidzieć i uwzględnić w organizacji pracy (np. Levinson, 1984).

Psychologia społeczna. Kariera jako odpowiedź jednostki na komunikaty z zewnątrz dotyczące ról i funkcji: podejście polegające na badaniu oddziaływania na psychikę konkretnych okoliczności zawodowych (np. Schneider i Hall, 1972; Bailyn, 1980).

Socjologia. Kariera jako realizacja funkcji społecznych: podejście to pokrywa się z podejściem psychologii społecznej, kładzie jednak większy nacisk na wkład jednostki w budowanie porządku społecznego (np. Huges, 1958; Van Maanen, Barley, 1984).

Kariera jako sposób na zapewnienie społecznej mobilności: postrzeganie funkcji zawodowej jednostki jako wskaźnika pozycji społecznej (np. Blau i Duncan, 1967; Featherman i Hauser, 1978; Warner i Abegglen, 1955).

Antropologia. Kariera jako wyznacznik statusu: podejście pokrywające się z podejściem socjologii funkcjonalnej, w którym rytuały i ceremonie zapewniają przetrwanie społeczeństwa lub kultury w czasie (np. Glaser i Strauss, 1971) $)^{27}$.

Psychologia i socjologia mają znaczący wkład w studia karierowe i mimo, co oczywiste, własnych obszarów problemowych oraz metod badawczych

\footnotetext{
${ }^{26}$ Tamże, s. 8.

${ }^{27}$ M.B. Arthur, D.T. Hall, B.S. Lawrence (red.), Handbook of Career Theory, s. 10.
} 
nadal oddziałują na te studia i profesjonalne praktyki z nimi związane, zapewniając dalszy ich rozwój. W wielu opracowaniach podkreśla się znaczenie wyjątkowego wkładu teorii socjologicznych w eksplantacje tyczące przebiegu karier czy przeobrażeń wzorów ich przebiegu poprzez usytuowanie ich w określonym kontekście społecznym. Ujmując zagadnienie w perspektywie historycznej, podkreśla się znaczenie prac M. Webera dotyczących protestanckiej etyki pracy i ducha kapitalizmu, relacji między ekonomią a wartościami ${ }^{28}$.

Intelektualne korzenie studiów karierowych stanowią, na co zwraca się uwagę $\mathrm{w}$ wielu opracowaniach dotyczących tego tematu, prace F. Parsonsa, E. Durkheima, E. Goffmana, H. Beckera, czy E. Scheina. Fundamentalne dla studiów karierowych są prace Z. Freuda, Maslowa, Eriksona, czy późniejsze prace Daltona (89), które zapewniły podstawy dla teorii rozwojowych ${ }^{29}$.

Problematyka miejsca pracy w życiu człowieka nabrała szczególnego znaczenia w historii rozwoju teorii karier w latach siedemdziesiątych XX wieku, określanych jako katalityczne ${ }^{30}$ dla teorii karier, kiedy to pojęcie kariery zostało zredefiniowane i wyłoniły się nowe obszary badawcze w tym obszarze. C.B. Derr i J.P. Briscoe podkreślając inspirujący wpływ prac D. Supera (1957), zwracają uwagę także na trzy podstawowe dla tej problematyki prace z tamtych lat: D.T. Halla (1976), E. Scheina (1978) i J. Van Maanena (1977), które stworzyły podbudowę dla prac aplikacyjnych nad karierami. DeLong (1982) wsparł ewidencjami empirycznymi koncepcje E. Scheina (1977), uszczegóławiając koncepcję kotwic kariery i rozwinął kwestionariusz umożliwiający ich analizę, również C.B. Derr bazując na koncepcji E. Scheina odkrył nowe kotwice kariery $(1980,1982)$. Jego późniejsza teoria dotycząca mapowania sukcesu w karierze identyfikuje pięć podstawowych orientacji karierowych, mogących się zmieniać w przestrzeni czasu i wymagających różnych strategii zawodowych mających zastosowanie w zawodzie i organizacjach. Wielu badaczy karier upatruje inspiracji badawczych w pracach wspomnianego wyżej E. Scheina i Sloan School of Management w Massachusetts Institute of Technology (MIT), w której swoje działania zaznaczyli tacy badacze, jak: D.T. Hall, L. Bailyn, D. Kolb, J.Van Maanen, B. Lawrence, J. Kotter, czy R. Katz ${ }^{31}$. Znaczącą rolę odegrało także „Mobilne Seminarium Karierowe” (Mobile Career Seminar) organizowane przez D. Supera, na którym poruszano wiele istotnych problemów z obszaru doradztwa zawodowego i edukacyjnego, a także badań zachowań mających miejsce w organizacjach. Przyjęta tam perspektywa

\footnotetext{
${ }^{28}$ M.T. Maranda, Y. Rameau, Some contribution of sociology to the understanding of career, [w:] The Future of Career.

${ }^{29}$ C. Moore, H. Gunz, D.T. Hall, Tracing the Historical Roots.

${ }^{30}$ C.B. Derr, J.P. Briscoe, The Catalytic1970s. Lessons for the 2000s, [w:] Handbook of Career

${ }^{31}$ C.B. Derr, J.P. Briscoe, The Catalytic1970s, s. 529.
} Studies. 
postrzegania tych zagadnień doprowadziła w efekcie do znacznych zmian w praktyce organizacji. Kariery zaczęto postrzegać jako wynik negocjacji pomiędzy organizacją a jednostką. Zmiany te zapewniały żyzny grunt pod dalsze studia karierowe, także $w$ obszarze badań nad organizacjami ${ }^{32}$.

Wkład studiów karierowych $\mathrm{z}$ lat siedemdziesiątych $\mathrm{XX}$ wieku stanowi pogłębione analizy dotyczące zarówno karier w wymiarze subiektywnym, jak i organizacyjnym, karier wewnętrznych, jak i zewnętrznych. Opracowanie autorstwa C.B. Derra oraz J.P. Briscoe, pod znamiennym tytułem, który już wcześniej przytaczałam: Katalityczne lata 70 - lekcje dla lat 2000, wskazuje na ważkość podejmowanych w tych latach studiów, które przyczyniają się do rozumienia indywidualnych wyborów karierowych, wymiarów sukcesów w karierze, determinant i przejawów satysfakcji zawodowej, czy przemian we wzorach przebiegu karier jako następstw przeobrażeń w sferze pracy w związku z procesem przechodzenia do gospodarki opartej na wiedzy.

W kontekście powyższych analiz dotyczących intelektualnych korzeni studiów karierowych usytuowanych w obszarze socjologii zrozumiały jest ten współczesny ich nurt, który docieka zróżnicowania karier w określonych środowiskach społecznych. C.B. Derr i J.P. Briscoe wskazują na wiele znaczących badań, które można do niego zaklasyfikować. Podkreślają między innymi znaczenie badań nad karierami kobiet, szczególnie w kontekście problemów społecznych w Stanach Zjednoczonych - praw kobiet w środowisku pracy, równości szans i barier, zwracają też uwagę na istotny w ich ocenie dorobek J. Van Maanena $(1977 b, 1982)$ oraz innych autorów ukazujących kariery jako metafory dla rozumienia kultury czy społecznej tożsamości jednostek ${ }^{33}$.

Poszerzenie analiz zorientowanych na zmieniający się kontekst karier umożliwia postrzegać je także poza środowiskiem zawodowym, szczególnie w odniesieniu do klasy średniej. Takie ujęcie karier pozwala również na analizy karier zróżnicowanych socjo-ekonomicznie, statusem, kulturą, płcią, przynależnością do określonej kohorty wiekowej ${ }^{34}$. W tym społecznym nurcie istotne znaczenie mają prace nad karierami bez granic, redukujące w określonym zakresie i równocześnie poszerzające społeczny kontekst karier (Arthur, Inkson, Pringle, 1999). Jest to nadal zajmujący badaczy ważny obszar dociekań. Szczególnie płodny kontekst badań stanowią badania nad zmianami relacji społecznych w środowisku pracy (Rousseau, 1995), czy nad indywidualną percepcją karier w czasach szybkich zmian ich społecznego kontekstu (Hall, Moss, 1998 $)^{35}$. Bardzo żywotny nurt badań w omawianym obszarze stanowią badania nad makrospołecznym ich kontekstem czy klasowym ich uwarun-

\footnotetext{
${ }^{32}$ Przedmowa do: Handbook of Career Studies, s. XVI.

33 C.B. Derr, J.P. Briscoe, The Catalytic1970s.

${ }^{34}$ E.H. Schein, Career Research. Some Personal Perspective, [w:] Handbook of Career Studies.

${ }^{35}$ C.B. Derr, J.P. Briscoe, The Catalytic1970s, s. 532.
} 
kowaniem. Znaczącym obszarem współczesnych studiów karierowych inspirowanym dokonaniami lat siedemdziesiątych $\mathrm{XX}$ wieku pozostaje dynamika karier wewnętrznych. C.B. Derr i J.P. Briscoe wskazują w tym obszarze między innymi na prace Briscoe, Halla i De Muth (2006), którzy opracowali narzędzia opisywania postaw proteuszowych i karier bez granic ${ }^{36}$. Wkładem lat siedemdziesiątych $\mathrm{w}$ studia karierowe o znaczeniu nie do przecenienia są opracowania koncepcyjne karier organizacyjnych i karier jednostkowych, czy też dotyczące ich wymiaru wewnętrznego i zewnętrznego. Dzięki tym dokonaniom możliwa jest dalsza integracja badaczy zajmujących się problematyką karier i rozumienie jej znaczenia w perspektywie globalnej i wielokulturowej, $\mathrm{w}$ coraz bardziej złożonym wewnętrznym i zewnętrznym środowisku ${ }^{37}$.

Warto podkreślić, że wyszczególnienie pól badawczych w analizach dynamiki rozwoju studiów karierowych niewątpliwie stwarza pewne trudności, na co zwracają uwagę H. Gunz i M. Peiperl, podając jako przykład strukturę różnego rodzaju handbooków z tego obszaru. Jak wskazują, włączenie do analiz pewnych problemów bądź wykluczenie innych jest zawsze kwestią dyskusyjną ${ }^{38}$.

Fundamentalne, jak wskazywałam wcześniej, dla studiów karierowych prace Freuda, Junga, Maslowa, Eriksona, czy późniejsze prace Daltona zapewniły, jak pokazują C.B. Derr i J.P. Briscoe, podstawę dla dalszych teorii rozwojowych. Przykładem efektów tych naukowych inspiracji są prace Drivera (1980) ukazujące to, jak koncepcje kariery wpływają na style podejmowania decyzji i jak te teoretyczne przesłanki służą rozwojowi organizacji, czy prace C.B. Derra (1986) nad rozwojem systemu nagród czy też rozwojem map sukcesu w przestrzeni czasowej ${ }^{39}$.

W budowie transdyscyplinarnych studiów szczególne znaczenie ma zwrócenie uwagi na emergencję i względność jako wyróżniające własności $\mathrm{w}$ domenie teorii karier. Wyobrażenia na temat karier w wymiarze czasowym mają bezpośredni wpływ na to, jak kariery są postrzegane w przestrzeni społecznej. Właściwość teorii karier, jaką jest emergencja, oznacza, że teorie te podejmują próby wyjaśnienia tego, w jaki sposób ludzie doświadczają czasu, zaś względność oznacza wyjaśnienie przez teorię doświadczania przestrzeni społecznej. Można zatem powiedzieć, że studia nad czasem i przestrzenią $\mathrm{w}$ obszarze pracy są inherentne dla teorii karier ${ }^{40}$. Zainteresowanie czasem jest explicite wyrażone $\mathrm{w}$ podstawowej definicji kariery zbudowanej przez M.B. Arthura, ujmującej ją jako gromadzenie doświadczeń wraz z zaawansowa-

\footnotetext{
36 Tamże, s. 531.

37 Tamże, s. 535.

${ }^{38}$ H. Gunz, M. Peiperl, Introduction, [w:] Handbook of Career Studies.

39 C.B. Derr, J.P. Briscoe, The Catalytic1970s, s. 531.

${ }^{40}$ M.B. Arthur, D.T. Hall, B.S. Lawrence (red.), Handbook of Career Theory, s. 12.
} 
niem w procesie pracy, co pozwala na przykład wyjaśnić - odmiennie niż w innych eksplantacjach satysfakcji z pracy czy też jej motywacji - dlaczego ludzie reagują odmiennie na te same sytuacje pracy w różnych etapach życia ${ }^{41}$.

Zmieniające się konstrukcje czasu i przestrzeni ujmuje się jako szerszy kontekst rozumienia zmian karier i planowania przyszłości karierowej jednostki oraz kształtowania jej tożsamości, który pozwala zrozumieć karierę jako współczesną personalną trajektorię, lecz odzwierciedlającą złożoność, różnorodność i fragmentaryzację życia w postmodernistycznym świecie. Zrewidowane współcześnie interpretacje karier uznają ich dualistyczny charakter, obejmujący teorię i praktykę, i zapewniają podstawy dalszego rozwoju, który uwzględnia społeczny kontekst, uznaje rolę doświadczenia i języka w konstrukcji znaczeń, a także naświetla znaczenie kulturowej różnorodności. Ta orientacja w przyszłość w teoriach rozwoju karier prezentuje odejście od indywidualizmu, monokulturowości i obiektywizmu, założonych implicite we większości teorii karier i praktyce, od czasu ich pojawienia się jako istotnego fenomenu w modernistycznej kulturze Zachodu. Nowe koncepcje tworzą grunt dla rozumienia roli doświadczenia i osiągania emancypatoryjnej praktyki ${ }^{42}$, zaś teoretyczne podejścia budują pejzaż odniesień dla różnie ujmowanej problematyki karier, stanowiąc podstawy do dalszych poszukiwań istotnych eksplantacji tego psychospołecznego fenomenu, służąc równocześnie jako ogniwo łączące transdyscyplinarne studia.

Akcentowane wcześniej socjologiczne i psychologiczne odniesienia pozwalają rozumieć karierę w relacji do koncepcji działań i projektów reprezentujących zarówno społeczne osadzenie, jak i zachowania nastawione na realizację wartości jednostki ${ }^{43}$. Warto może w tym miejscu nadmienić, że praktyka doradcza, uwzględniająca zmienność karier, utożsamiana jest ze znaczącą praktyką społeczną ${ }^{44}$, zapewniającą nie tylko określone formy usług, ale dotyczącą podstawowych kwestii życia we współczesnym świecie i środowisku pracy.

Szczegółową historię spotkań badaczy podejmujących problematykę karier na przestrzeni lat osiemdziesiątych i dziewięćdziesiątych XX wieku przedstawiają C.B Deer i J.P. Briscoe. Inspirujące rozwój studiów karierowych dyskusje dotyczyły tego, czy dotychczasowe dokonania w analizowanym obszarze są wystarczającą podstawą do tworzenia nowej subdyscypliny. Jak podkreślają, dla współczesnych studiów karierowych znaczenie mają badania i dyskusje nie tylko w kontekście amerykańskim czy problemów

41 Tamże.

${ }^{42}$ R.A. Young, A. Collin, Introduction: Flaming the future of career, [w:] The Future of Career, s. 150 .

${ }^{43}$ R.A. Young, L. Valach, Reconceptualising career theory and research: an action - theoretical perspective, [w:] The Future of Career. Tamże.

${ }^{44}$ F.T.L. Leong, P.J. Hartung, Adapting to the changing multicultural context of career, [w:] 
Zachodu; w globalnym świecie rośnie bowiem znaczenie perspektywy międzykulturowej. Badacze ci nawołują o niepowtarzalnego ducha integracji społeczności uczonych podejmujących problematykę karier w latach siedemdziesiątych XX wieku, przywołując otwartość, uwzględnianie perspektywy rozwojowej i postrzeganie jednostek w całokształcie ich życiowych sytuacji. Wskazują też na konieczność kulturowo zróżnicowanych podejść, potrzebę wzajemnego uczenia się z akceptacją różnorodności perspektyw, uwzględniania znaczenia teorii karier dla jednostek i organizacji ${ }^{45}$.

Lata 2000 w studiach karierowych stanowią budowę dialogu i społeczności badaczy zajmujących się tą problematyką w globalnym kontekście, z uwzględnieniem geograficznych, kulturowych, czy też ideologicznych zróżnicowań tła kształtowania się i przebiegu karier ${ }^{46}$.

Wyraźnym nurtem analiz są "stare" problemy w nowym kontekście, jak na przykład kwestie dotyczące zewnętrznej adaptacji w relacji do wewnętrznej integracji, szczególnie przy założeniach dotyczących ważności problematyki karier dla studiów i praktyki w obszarze zarządzania. E.H. Schein zwraca uwagę na niezwykłą dynamikę studiów karierowych, mając na uwadze zarówno ekspansję obszarową, jak i tematyczną. Ukazując wybiórczo najistotniejsze kierunki przeobrażeń karier i tym samym studiów karierowych, można wskazać, że istotnym przedmiotem analiz badawczych jest wewnętrzny wymiar karier. Podejścia zorientowane na dynamikę karier wewnętrznych pozwalają zrozumieć nie tylko indywidualne doświadczenie kariery, lecz także, co bardzo ważne, naturę pracy i jej przeobrażenia, obszar, jak podkreśla E.H. Schein, często zaniedbany w studiach karierowych ${ }^{47}$. D.T. Hall, J.P. Briscoe i Kram (1997) czy w innych pracach D.T. Hall $(2002,2004)$ utrzymują, że „kariera jaką znamy umarła”, lecz żywa jest kariera proteuszowa o wyraźnym wymiarze wewnętrznym, czy inaczej psychologicznym. Także pojęcie kariery bez granic wykreowane przez M.B. Arthura i współpracowników mocno akcentuje wewnętrzny wymiar kariery (Arthur, Rousseau, 1996; Arthur, Klapowa, Widerom, 2005; DeFillippi, Arthur 1994) ${ }^{48}$. Można powiedzieć, że refleksja nad wewnętrznym wymiarem karier rysuje się jako wyraźny nurt studiów karierowych, a zagadnienia dotyczące perspektywy jednostkowej i organizacyjnej, czy też właśnie wymiaru wewnętrznego i zewnętrznego karier, stanowią znaczący wkład do ich rozwoju. W tym kontekście szczególnego znaczenia nabiera problem zewnętrznego i wewnętrznego wymiaru kariery. C.B. Derr i A. Laurent wskazują, że zmiany wewnętrznych orientacji karierowych, czy inaczej określając - zróżnicowanych personalnie

\footnotetext{
${ }^{45}$ C.B. Deer, J.P. Briscoe, The Catalytic1970s, s. 534-535.

${ }^{46}$ Tamże.

${ }^{47}$ E.H. Schein, Career Research.

${ }^{48}$ C.B. Derr, J.P. Briscoe, The Catalytic1970s, s. 531.
} 
orientacji w stosunku do pracy, mogą być konsekwencją nie tylko istotnych zdarzeń w sytuacji pracy, lecz szerzej ujmując - zmian zachodzących w życiu jednostki. Badacze ci podkreślają znaczenie kultury dla kształtowania się konstruktu, jakim jest kariera w jej wymiarze zarówno wewnętrznym, jak i zewnętrznym, kultura bowiem określa jej kształt i dynamikę. Ta wewnętrzna orientacja karierowa jest personalną i subiektywną mapą funkcjonującą na bazie podstawowych założeń odnośnie świata pracy, kształtowanych, jak wspomniałam, pod wpływem czynników kulturowych, także w szerszym, narodowym kontekście ${ }^{49}$. Zewnętrzną karierę jednostki opisują natomiast jako bezpośredni efekt oddziaływania określonych kultur organizacyjnych, które same stanowią element pośredni i różnicujący oddziaływania szerszego otoczenia kultury narodowej, także spoza kręgu kultury amerykańskiej i zachodniej, subkultur, różnych segmentów rynku pracy, na przykład robotników wykwalifikowanych, niewykwalifikowanych, kobiet i mężczyzn. Podczas kiedy, jak argumentują, "rzeczywisty świat karier” nie jest dychotomiczny, to odwołanie się do kategorii: kariera wewnętrzna - kariera zewnętrzna pozwala na lepsze zrozumienie dialektycznej gry pomiędzy jednostką a światem pracy. Poddają pod dyskusję problem obiektywnej rzeczywistości domeny kariery, pokazując możliwości interpretacyjne analizowanego obszaru ujmowanego jako społecznie konstruowana rzeczywistość, symboliczna reprezentacja wzorów pracy. Wskazują na to, że kariera wewnętrzna to więcej niż tylko wewnętrzna perspektywa, rzutuje ona bowiem na organizacyjne praktyki i systemy ${ }^{50}$. Znaczny obszar literatury dotyczący między innymi takich zagadnien, jak: kotwice kariery, orientacje karierowe, życie zawodowe a osobiste, praca w cyklach życia, poświęcony jest karierom wewnętrznym. Literatura dotycząca karier zewnętrznych ugruntowana jest $w$ obszarze organizacji pracy oraz zawodoznawstwie i podejmuje takie kwestie, jak między innymi: zewnętrzny i wewnętrzny rynek pracy, mobilność karierowa, fazy kariery, instytucjonalne systemy rozwoju karier, rozwój kariery. Warto podkreślić, że pojawiają się relatywnie nowe problemy dotyczące na przykład takich kwestii, jak relacje zachodzące między kulturą narodową a wewnętrzną karierą $\mathrm{w}$ wielonarodowych organizacjach, szczególnie ważne dla współczesnych studiów karierowych.

Powstało także wiele innych tematycznie prac inspirowanych katalitycznymi dla współczesnych studiów karierowych latami siedemdziesiątymi XX wieku. Jednym z głównych nurtów zainteresowań badaczy karier stały się relacje zachodzące między pracą a życiem osobistym: równowaga i konflikt pomiędzy życiem zawodowym a osobistym (Greenhaus, 1980; Beutell 1985;

${ }^{49}$ C.B. Deer, A. Laurent, The internal and external carer: a theoretical and cross - cultural perspective, [w:] Handbook of Career Theory, s. 458.

${ }^{50}$ Tamże, s. 465-467. 
Hall i Hall) ${ }^{51}$, zorientowane na wyjaśnienia możliwości osiągania równowagi między tymi podstawowymi domenami życia człowieka. Wiele prac badawczych w tym obszarze zorientowanych jest na wyjaśnienie wzajemnych relacji zachodzących pomiędzy sferą osobistą, karierą zawodową i fazami cyklu życia, ze szczególnym uwzględnieniem płci pracownika, czy perspektywy społecznej identyfikacji jednostki oraz jej systemu wartości. Praca często w tych ujęciach postrzegana jest jako czynnik utrudniający funkcjonowanie $\mathrm{w}$ rodzinie, ale również wzbogacający role spoza jej obszaru. Jak podkreślają badacze tych problemów, zagadnienie równowagi ważne jest zarówno z perspektywy pracownika, jak i zatrudniającej go organizacji.

Zachodzące w latach dziewięćdziesiątych XX wieku i wczesnych latach 2000 zmiany związane z przejściem od gospodarki przemysłowej do gospodarki opartej na informacjach prowokowały badania dotyczące tego, dlaczego i w jaki sposób jednostki dokonują wyborów karierowych, jakie są wymiary sukcesu w karierze, jak wygląda kariera w perspektywie organizacyjnej i jednostkowej. Istotnym nurtem studiów karierowych są badania nad karierami w ich społecznym kontekście. C.B. Derr i J.P. Briscoe wskazują na wiele znaczących badań, które zakwalifikować można do tego nurtu. Podkreślają między innymi znaczenie badań nad karierami kobiet, szczególnie w kontekście problemów społecznych w Stanach Zjednoczonych: praw kobiet w środowisku pracy, równości i barier w tym zakresie. Podkreślają dorobek J. Van Maanena i innych autorów ukazujących kariery jako metafory dla rozumienia problemów kultury pracy czy społecznej tożsamości jednostek (1977b, 1982). W nurcie społecznym istotne znaczenie mają prace nad karierami bez granic, redefiniujące i poszerzające społeczny kontekst karier (Arthur, Inkson, Pringle, 1999). Szczególnie płodny kontekst stanowią badania nad zmianami kontraktów społecznych w środowisku pracy (Rosseau, 1995), czy nad indywidualną percepcją karier w czasach szybkich zmian ich społecznego kontekstu (Hall, Moss, 1998). Bardzo żywotny nurt badań w omawianym obszarze stanowią badania nad makrospołecznym ich kontekstem, czy nad klasowym ich warunkowaniem ${ }^{52}$.

Kariera jest terminem wielowarstwowym i niejednoznacznym, co umożliwia stosowanie go w różnych kontekstach i stanowi główne źródło jego wagi. Niezależnie jednak od kontekstualnych zastosowań i funkcji jej przypisywanych, kariera wiąże przeszłość i teraźniejszość poprzez antycypację zmian w obszarze pracy i kultury, co odnosi się do planowania określonych działań i konstrukcji znaczeń w teraźniejszości. Jak podkreślają R.A. Young i A. Collin, przyszłość kariery warunkowana informacjonizmem, globaliza-

\footnotetext{
51 Za: tamże, s. 532.

52 Za: tamże.
} 
cją i możliwościami zastosowań nowych technologii ma wyraźne implikacje dla kształtowania się tożsamości jednostek, a także dla całokształtu biegu ich życia, jest bowiem karierą konstruktem nadającym znaczenie życiu. Dyskusje podejmowane $\mathrm{w}$ studiach karierowych odzwierciedlają ukryte napięcie między karierą jako artefaktem świata techniki, produkcji, administracji oraz szerszymi zmianami społecznymi i leży u podstaw współczesnego dylematu tożsamości ${ }^{53}$.

Zrewidowane interpretacje kariery ze względu na zachodzące $\mathrm{w}$ ich kontekście zmiany oraz nowe wyzwania uznają ich dualność wynikającą z podziału na retorykę i określoną praktykę społeczną. Stanowi to podwaliny rozwoju polegającego na budowaniu kariery w kontekście społecznym, w którym uznaje się ogromną rolę doświadczenia i języka w tworzeniu znaczeń i wyjaśnianiu zmienności kulturowej. Rozwój ten jest zasadniczym odejściem od koncepcji indywidualizmu i monokulturowości, które w warstwie interpretacyjnej zawierały się w znacznej części teorii, praktyki i retoryki karier od czasu przyjęcia nowoczesnego podejścia do tej koncepcji. Wspomniany rozwój jest szansą na ugruntowanie rozumienia kariery w doświadczeniu człowieka i wypracowaniu na tej podstawie emancypatoryjnej praktyki ${ }^{54}$.

D. Gowler i K. Legge mówią także o transformacyjnych teoriach karier jako wizji przyszłości. Postrzegają pole teorii karier jako forum transdyscyplinarnych studiów nad relacjami człowiek - praca. Jako uzasadnienie takiego stanowiska przytaczają dwie główne charakterystyki teorii karier. W pierwszej koncepcja kariery zachęca do budowania teorii, które skupiają się zarówno na jednostkach, jak i instytucjach, w drugiej koncepcja ta prowadzi do tworzenia teorii opartych na emergencji i względności ${ }^{55}$.

Współczesne teorie karier to odrębne próby rozszerzenia analizy o nowe obszary, a także forum konstruktywnej debaty nad ideami i praktycznymi zastosowaniami. Jest to równocześnie forum starcia się różnych poglądów, na przykład od ortodoksyjnej socjologii po krytyczne podejścia na temat kondycji i rozwoju jednostek, które te teorie łączą inspirując nowe problemy badawcze i możliwości ${ }^{56}$.

Współczesne studia karierowe dociekają, na ile nasze przeszłe oraz teraźniejsze rozumienie i doświadczenia kariery kontynuowane będą $\mathrm{w}$ przyszłości. Istotne jest doświadczenie nieciągłości, które stanowi wyzwanie dla fundamentalnych zasad i standardów, na których opierają się teorie, badania i praktyki w zakresie karier ${ }^{57}$. Stawiane są pytania: czy doświadczanie nie-

\footnotetext{
${ }^{53}$ R.A. Young, A. Collin, Introduction: framing the future of career, s. 8.

${ }^{54}$ Tamże.

${ }^{55}$ D. Gowler, K. Legge, Rhetoric in bureaucratic careers.

${ }^{56}$ R.A. Young, A. Collin, Introduction: framing the future of career, s. 20.

57 Tamże.
} 
ciągłości i, jak wskazuje A. Collinn ${ }^{58}$, niemożności w miarę przewidywalnego lokowania siebie w przestrzeni społecznej eroduje użyteczność kariery jako konstruktu i jako obszaru badań. Jeśli bowiem doświadczamy wirtualnej „śmierci" kariery, problemem staje się też rekonceptualizacja tej kategorii i poszukiwanie odpowiedzi na pytanie, jaka jest jej przyszłość, jakie jawią się nowe tematy z nią związane i jakie są ich implikacje?

\section{BIBLIOGRAFIA}

Alurmani G., Striking to Wright note: The cultural preparedness approach to developing resonant career guidance programme, International Journal for Education and Vocational Guidance 2011, 11.

Arthur M.B., Lawrence B.S., Perspectives on environment and career. An introduction, Journal of Occupational Behaviour, 1984, 5.

Burszta J., Ruchome wyobraźnie. Reżim mobilności w neoliberalnym świecie, [w:] Zwodnicze imaginarium. Antropologia neoliberalizmu, red. W.J. Burszta, P. Jezierski, M. Rauszer, Katedra Wydawnictwo Naukowe, Gdańsk 2016.

Castells M., Społeczeństwo sieci, Wydawnictwo Naukowe PWN, Warszawa 2013.

Collin A., Dancing to the music of time, [w: The Future of Career, red. A. Collin, R.A. Young, Cambridge University Press, Cambridge 2000.

Deer C.B., Laurent A., The internal and external career: a theoretical and cross - cultural perspective, [w:] Handbook of Career Theory, red. M.B. Arthur, D.T. Hall, B.S. Lawrence, Cabridge University Press, Cambridge 1996.

Derr C.B., Briscoe J.P., The Catalytic1970s. Lessons for the 2000s, [w:] Handbook of Career Studies, red. H. Gunz, M. Peiperl, Sage Publications, Los Angeles 2007.

Gowler D., Legge K., Rhetoric in bureaucratic careers: managing the meaning of management success, [w:] Handbook of Career Theory, red. M.B. Arthur, D.T. Hall, B.S. Lawrence, Cambridge University Press, Cambridge 1996.

Gunz H., Peiperl M., Introduction, [w:] Handbook of Career Studies, red. H. Gunz, M. Peiperl, Sage Publications, Los Angeles 2007.

Hall D.T., Mirvis P.H., The new protean career. Psychological success and the path with a heart, [w:] The career is dead - long live the career, red. D.T. Hall, Jossey-Bass, San Francisco 1996.

Leong F.T.L., Hartung P.J., Adapting to the changing multicultural context of career, [w:] The Future of Career, red. A. Collin, R.A. Young, Cambridge University Press, Cambridge 2000.

Leung S.A., The Big Five Theories, [w:] International Handbook of Career Guidance, red. J.A. Athanasou, R. Van Esbroeck, Springer 2008.

Maranda M.T., Rameau Y., Some contribution of sociology to the understanding of career, [w:] The Future of Career, red. A. Collin, R.A. Young, Cambridge University Press, Cambridge 2000.

Marody M., Jednostka po nowoczesność. Perspektywa socjologiczna, Wydawnictwo Naukowe Scholar, Warszawa 2014.

Marody M., Lewicki L., Przemiany ideologii pracy, [w:] Kultura i gospodarka, red. J. Kochanowicz, M. Marody, Wydawnictwo Naukowe Scholar, Warszawa 2010.

${ }^{58}$ A. Collin, Dancing to the music of time, [w:] The Future of Career. 
Moore C., Gunz H., Hall D.T., Tracing the Historical Roots of Career Theory in Management and Organizational Studies, [w:] Handbook of Career Studies, red. H. Gunz, M. Peiperl, Sage Publications, Los Angeles 2007.

Savickas M.L., Renovating the psychology of career for the twenty - first century, [w:] The Future of Career, red. A. Collin, R.A. Young, Cambridge University Press, Cambridge 2000.

Schein E.H., Career Research. Some Personal Perspective, [w:] Handbook of Career Studies, red. H. Gunz, M. Peiperl, Sage Publications, Los Angeles 2007.

Sennett R., Korozja charakteru. Osobiste konsekwencje pracy w nowym kapitalizmie, Wydawnictwo Literackie Muza, Warszawa 2006.

Sonnenfeld J.A., Kotter J.P., The maturation of career theory, Humans Relations, 1982, 35.

Van Maanen J., Organizational Careers: Some New Perspectives, Willey, New York 1977.

Young R.A., Collin A., Introduction: framing the future of career, [w:] The Future of Career, red. A. Collin, R.A. Young, Cambridge University Press, Cambridge 2000.

Young R.A., Valach L., Reconceptualising career theory and research: an action - theoretical perspective, [w:] The Future of Career, red. A. Collin, R.A. Young, Cambridge University Press, Cambridge 2000. 
